\title{
Disability in employment equality law: A reappraisal of the reasonable accommodation duty and issues arising in its implementation
}

Maastricht Journal of European and Comparative Law 202I, Vol. 28(6) 744-759 (C) The Author(s) 2021

(c) (i)

Article reuse guidelines: sagepub.com/journals-permissions DOI: $10.1177 / 1023263 \times 211035268$ maastrichtjournal.sagepub.com

(SAGE

\section{Patrick Daly* and Darius Whelan**(1)}

\begin{abstract}
This article re-considers the special features of the disability ground in EU equality law and raises questions as to whether the EU's Framework Equality Directive (Directive 2000/78) may be in need of fundamental reform. It argues that the 'Competence Defence' in the Directive could have been more strongly drafted, to prescribe more precisely the circumstances in which an individual may be found not to be competent to perform the post's essential functions. In the absence of a unified EU approach regarding the activation of the reasonable accommodation duty and an employer's knowledge as to disability or the need for reasonable accommodation, national positions are compared. A model whereby the provision for individuals with disabilities is carried out in a proactive as opposed to a reactive manner could reduce the need for the reasonable accommodation system. The possibility of increased state involvement in the provision of reasonable accommodation to employees has strong potential. It is proposed that the principle of Universal Design, as expressed in the Convention on the Rights of Persons with Disabilities, could be used to ensure that work environments are developed from the outset to be conducive to the needs of those with physical or psychosocial disabilities. The implications of such a major change are assessed.
\end{abstract}

\section{Keywords}

Disability, employment equality, convention on the rights of persons with disabilities, reasonable accommodation, universal design

\footnotetext{
* Unaffiliated

** School of Law, University College Cork, Cork, Ireland
}

\section{Corresponding author:}

Darius Whelan, Senior Lecturer, School of Law, University College Cork, Cork, Ireland.

E-mail: d.whelan@ucc.ie 


\section{Introduction}

The disability ground in employment equality law is the focus of a great deal of academic discussion. It has led to some high profile CJEU cases such as Chacon Navas ${ }^{1}$ and more recently V.L. ${ }^{2}$ At the Member State level, in Ireland the Supreme Court recently decided the Nano Nagle case, ${ }^{3}$ which has been the subject of detailed analysis. ${ }^{4}$ In the UK, the Court of Appeal has also recently considered the disability ground in the Donelien case. ${ }^{5}$ Disability and human rights are under more detailed scrutiny in recent years, given the adoption of the Convention on the Rights of Persons with Disabilities (CRPD) ${ }^{6}$ and the Sustainable Development Goals. ${ }^{7}$ This article will reconsider the special features of the disability ground in EU equality law and raise questions as to whether the EU's Framework Equality Directive (Directive 2000/78) may now be in need of a more fundamental reform.

The article begins in section 2 with a brief review of some of the special considerations which apply to the disability ground, especially the reasonable accommodation duty and the disproportionate burden defence. Section 3 examines the competence defence, which states that the employer is not required to recruit an individual, or maintain them in employment, if they are not competent to perform the essential functions of the post, provided reasonable accommodation has been made. In Section 4, we discuss when the reasonable accommodation duty is activated, and the particular difficulties this raises, for example in the case of those with psychosocial disabilities. Section 5 considers potential solutions to the issues raised in the earlier parts. The potential to enhance state involvement in the process of reasonable accommodation is highlighted, and the prospect of Universal Design being adopted as an overarching new principle in EU equality law is discussed.

\section{The disability ground - special considerations}

Discrimination against persons with disabilities in employment is widespread and well documented. In 2018, there was a $75 \%$ employment rate for people with no disability in the EU, but this reduced to $58.3 \%$ for those with moderate disability and $28.7 \%$ for those with severe disability. ${ }^{8}$

1. Case C-13/05 Chacón Navas v Eurest Colectividades SA, EU:C:2006:456; L. Waddington, 'Case C-13/05, Chacón Navas v. Eurest Colectividades SA, judgment of the Grand Chamber of 11 July 2006', 44 Common Market Law Review 487 (2007).

2. Case C-16/19 V.L. v Szpital Kliniczny im. dra J. Babin'skiego Samodzielny Publiczny Zakład Opieki Zdrowotnej w Krakowie, EU:C:2021:64.

3. Nano Nagle School v Daly [2019] IESC 63.

4. D. Ryan and M. Bell, 'Disability, Reasonable Accommodation and the Employer's Obligations: Nano Nagle School v Daly', 83 Modern Law Review (2020), p. 1059; S. Quinlivan and C. O'Mahony, 'The Irish Supreme Court Judgment in Nano Nagle School v Marie Daly: A Saga of Litigation', 70 Northern Ireland Legal Quarterly (2019), p. 505; L.-A. Buckley and S. Quinlivan, 'Reasonable Accommodation in Irish Equality Law: an Incomplete Transformation', 41 Legal Studies (2021), p. 19; E. O’Connor and E. O'Callaghan, 'Reasonable Accommodation and the Disabled Employee: Nano Nagle School v Marie Daly’, 16 Irish Employment Law Journal (2019), p. 104 .

5. Donelien v Liberata UK [2018] EWCA Civ. 129; [2018] IRLR 535.

6. United Nations Convention on the Rights of Persons with Disabilities, 13 December 2006, A/RES/61/106.

7. United Nations, Transforming Our World: The 2030 Agenda for Sustainable Development, Resolution adopted by the General Assembly on 25 September 2015, A/RES/70/1. Disability is highlighted in a number of the goals, for example Goals 4, 10 and 17.

8. European Disability Expertise, Master Tables Concerning EU 2020: year 2018, Table 2. 
Eurostat reported in 2015 that less than one person out of two in the EU (47\%) with basic activity difficulties was employed. ${ }^{9}$ This compared with a $67 \%$ employment rate for those who did not have such difficulties. It appears that numbers of employment equality claims on the disability ground lodged in Europe are at high levels. ${ }^{10}$ Academic research has shown that employers often harbour pessimistic views about the work-related abilities of individuals with disabilities. ${ }^{11}$ The Covid-19 pandemic and resulting economic shocks increase the vulnerability of persons with disabilities to further inequalities. ${ }^{12}$

While all grounds of discrimination are subject to particular provisions, exceptions or limitations in the various EU Equality Directives, the disability ground includes a special provision which is of quite a different character to the others, i.e. the Reasonable Accommodation duty. ${ }^{13}$ On reviewing Directive 2000/78, ${ }^{14}$ for example, it stands out as a provision like no other in that Directive. The Directive recognizes that it would not be sufficient to provide that people with disabilities should receive equal treatment in employment; there must also be an added requirement that the employer must accommodate persons with disabilities. But the requirement is qualified in a number of ways. For example, it is described as 'reasonable' accommodation and it is stated that it applies 'unless such measures would impose a disproportionate burden' on the employer. We will refer to this as the 'disproportionate burden defence'.

Why is the disproportionate burden defence available to employers at all? It undermines equal participation for people with disabilities, as it sends the message that, if an employer can avail of the disproportionate burden defence, the employee need not be treated equally. One response may be that equality law may sometimes involve treating different people differently, and that the reasonable accommodation duty is actually a benefit to a person with a disability. However, a purer form of equality would require that all employees, including those with disabilities, be accommodated, regardless of the cost, inconvenience or other burden to the employer.

Recital 21 of the Framework Directive states that in assessing whether a disproportionate burden has arisen, account should be taken 'in particular of the financial and other costs entailed,

9. Eurostat, International Day of Persons with Disabilities (2015), https://ec.europa.eu/eurostat/news/themes-in-thespotlight/disability-statistics.

10. Statistics from some member states are available in the national reports from the European network of legal experts in gender equality and non-discrimination available at www.equalitylaw.eu/country. Some examples: (a) United Kingdom, 2018-2019: there were 4,935 Employment Tribunal disposals on the disability ground, which is higher than the figures regarding the race, age, religion and sexual orientation grounds; (b) The Netherlands, 2018: $25 \%$ of requests for an opinion from the Netherlands Institute for Human Rights related to discrimination on grounds of disability and chronic illness; (c) Ireland, 2019: 329 of 1,733 employment equality claims to the Workplace Relations Commission (19\%) concerned the disability ground; (d) Finland, 2018: the most common ground for reported instances of discrimination to the Non-discrimination Ombudsman was disability (192 of 924 cases, 21\%); (e) Norway, 2019: the Equality and Anti-Discrimination Ombud provided advice in 1,988 cases, of which 472 (24\%) concerned disability; (f) Sweden, 2019: the Equality Ombudsman received 2,661 complaints, of which 804 (30\%) concerned disability.

11. S. Bonaccio et al., 'The Participation of People with Disabilities in the Workplace Across the Employment Cycle: Employer Concerns and Research Evidence', 35 Journal of Business and Psychology (2020), p. 135 .

12. International Labour Organisation, COVID-19 and the World of Work: Ensuring the Inclusion of Persons with Disabilities at All Stages of the Response (2020).

13. For a general review of the law concerning the disability ground in Europe, see I. Chopin and C. Germaine, $A$ Comparative Analysis of Non-Discrimination Law in Europe 2019 (Publications Office of the European Union, 2020), p. 21.

14. Council Directive 2000/78/EC of 27 November 2000 establishing a general framework for equal treatment in employment and occupation, [2000] OJ L 303/16. 
the scale and financial resources of the organization or undertaking and the possibility of obtaining public funding or any other assistance'. One consequence of this is that what constitutes a disproportionate burden can vary based on the resources of the employer in question. This would also appear prima facie to contravene the very purpose of the Directive as set out in Article 1, that being to establish, inter alia, a framework to combat discrimination on the ground of disability and to put in place the principle of equal treatment. Were identical employees with identical disabilities to be employed with two similar employers, one with vast financial resources and the other with minimal financial resources, the employee employed with the latter employer may be afforded a lesser degree of protection under the Directive.

Recital 21 refers to the possibility of state funding or other assistance as a means of financing the appropriate measures. This requires employers to explore opportunities of state funding, but does not require states to provide any such funding. As will be discussed in section 5 below, some states have become more proactively involved in the reasonable accommodation process, and the funding of reasonable accommodation measures may be part of this state involvement. Stronger state involvement may need to be a component of more fundamental reform of equality law concerning disability in the future.

Equal treatment for persons with disabilities must also be read in light of Recital 17, which may be referred to as the 'Competence Defence'. The Recital states that the Directive does not require the recruitment, promotion, maintenance in employment or training of an individual who is not competent, capable and available to perform the essential functions of the post concerned or to undergo the relevant training, without prejudice to the obligation to provide reasonable accommodation for people with disabilities. The principle of Recital 17 is understandable, but issues arise as to the precise meaning of the recital.

As the Framework Directive was enacted six years before the adoption of the UN's Convention on the Rights of Persons with Disabilities (CRPD), its wording naturally does not take account of the ground-breaking principles enshrined in that Convention. The courts have made good efforts to use the CRPD to assist them in interpreting the Directive. As time goes on, the influence of the CRPD on judicial reasoning is becoming stronger and stronger. The CRPD has even been 'subtly constitutionalised' by the CJEU. ${ }^{15}$ But ultimately, ideas about human rights for persons with disabilities are moving on so much that the time may be approaching for a more profound rethinking and redrafting of equality law for people with disabilities in Europe.

\section{The competence defence}

The 'Competence Defence' states that the employer is not required to recruit an individual, or maintain them in employment, if they are not competent to perform 'the essential functions of the post concerned', provided reasonable accommodation which does not impose a disproportionate burden has been made. This provides generous wriggle room for an employer, who can argue that certain functions are 'essential', and the individual may have difficulty proving that they are not. The Directive provides no guidance concerning categorization of functions into essential and nonessential. There is evidence in Ireland that in quite a number of cases, claimants do not succeed

15. D. Ferri, 'The Unorthodox Relationship between the EU Charter of Fundamental Rights, the UN Convention on the Rights of Persons with Disabilities and Secondary Rights in the Court of Justice Case Law on Disability Discrimination', 16 European Constitutional Law Review (2020), p. 304. 
because they are deemed not to be 'competent'. ${ }^{16}$ In one case, an employee of the national rail company was considered not to be competent to perform a safety-critical role due to his epilepsy. ${ }^{17}$

The directive is silent about any possible procedural requirements for employers in making decisions about an individual's competence or about the issue of reasonable accommodation. Some national courts have held, for example, that an employer must consult with the employee on these issues, but it would be better if the directive recognized the importance of such matters through explicit reference to them. National courts have also held, however, that any such procedural duty is not a separate and distinct one and, if it has been breached, it does not automatically follow that the reasonable accommodation duty has been breached. ${ }^{18}$

Another issue is whether, in cases where the individual cannot perform essential functions, there is a duty on the employer to re-distribute essential functions to other workers. Recital 20 is of some assistance here, stating that appropriate measures to accommodate workers with disabilities can include, for example, 'the distribution of tasks'. This is reflected in national legislation in Ireland ${ }^{19}$ and in the views of the UN Committee on the Rights of Persons with Disabilities. ${ }^{20}$ The CJEU has not made explicit statements as to whether this extends to distribution of essential tasks. ${ }^{21}$ It was unclear in Irish law until 2019 whether distribution of tasks could apply to essential functions. ${ }^{22}$ Recently, in the major case of Nano Nagle School v Daly, one court - the Court of Appeal provided a narrow interpretation of recital 17 and the national implementing measure, holding that an employee's main duties could not be redistributed to others as part of a process of reasonable accommodation. ${ }^{23}$ This interpretation was later reversed by the Supreme Court. ${ }^{24}$ The court said, however, that the duty of accommodation is not an open-ended one and a situation may be reached where the degree of re-arrangements necessary, whether by allocation of tasks or otherwise, might be such as to be disproportionate. ${ }^{25}$

If the employee is not competent to perform the role even after reasonable accommodation has been provided, is there a duty on the employer to provide them with another job within the same organization if one is available? The wording of Recital 17 refers to 'the essential functions of the post concerned' (emphasis added) and arguably this indicates that transfer to another job is not contemplated. ${ }^{26}$ In the UK, the House of Lords held in Archibald v. Fife Council ${ }^{27}$ that in some circumstances, there might be a duty on the employer to transfer the employee to another role, if

16. National Disability Authority, Reasonable Accommodations: Obstacles and Opportunities to the Employment of Persons with a Disability (2019), p. 7. In 11 cases of 82 reviewed, the Workplace Relations Commission or Labour Court determined that there was no breach of the reasonable accommodation requirement because the employee would not have been fully competent to undertake the role even with a reasonable accommodation.

17. Iarnród Éireann v. Flanagan, EDA1716, Labour Court, 2017.

18. See for example Tarbuck v Sainsbury Supermarkets Ltd [2006] IRLR 664 (UK EAT); Nano Nagle School v Daly [2019] IESC 63.

19. Employment Equality Act 1998, as amended, s.16(4)(b).

20. Committee on the Rights of Persons with Disabilities, General Comment No 6 - Equality and Non-discrimination (2018), para. 23, which refers to 'reorganizing activities' as a form of reasonable accommodation.

21. D. Ryan and M. Bell, 83 Modern Law Review (2020), p. 1064.

22. M. Bell, 'Pitfalls and Progress: Reasonable Accommodation for Workers with Disabilities in Ireland', 41 Dublin University Law Journal (2018), p. 90.

23. Nano Nagle School v Daly [2018] IECA 11.

24. Nano Nagle School v Daly [2019] IESC 63.

25. Ibid., majority judgment, para. 106.

26. D. Ryan and M. Bell, 83 Modern Law Review (2020), p. 1065.

27. [2004] IRLR 651. 
one was available. Irish case-law has been inconsistent on this point. ${ }^{28}$ In the Nano Nagle case, the Supreme Court said that the distribution of duties should not lead to the creation of an entirely different job for the employee. ${ }^{29}$ In Belgium, the matter has arisen in a case concerning a railway maintenance technician with a pacemaker. ${ }^{30} \mathrm{He}$ could no longer work near railway tracks due to the risk from the electromagnetic fields, and the company dismissed him as not competent to perform his job. He argued that the company should provide him with a different job in a warehouse. The Conseil d'État decided to refer a question of law to the CJEU as to whether the directive means that an employer must assign the employee to another post if this would not impose a disproportionate burden on the employer. The CJEU's ruling on this matter will be read with great interest and may bring some clarity on this point.

Article 5(3) of the CRPD states that, in order to promote equality and eliminate discrimination, states parties shall take all appropriate steps to ensure that reasonable accommodation is provided. A definition of 'reasonable accommodation' is provided in Article 2, and this does not include any 'competence defence' or any reference to essential job functions. ${ }^{31}$ The UN Committee on the Rights of Persons with Disabilities has issued a detailed General Comment on equality, which also contains no competence defence. ${ }^{32}$ Ryan and Bell note that this leans in favour of the employer being open to a variety of measures without imposing any automatic exclusions from the outset. ${ }^{33}$ Increasingly, courts are relying on the CRPD as an aid to interpreting EU and national law, and thus there may be a general shift towards an interpretation of the competence defence which requires the employer to consider far-reaching measures to accommodate the individual.

\section{Duty activation}

There are important questions regarding the point at which the employer becomes duty-bound to provide or to assess the viability of providing reasonable accommodation. There are various dutyactivation models in use; we will discuss which model is most conducive to the prevention of unfavourable treatment of persons with disabilities and most practical for employees and dutybearers.

Examination of psychosocial disabilities (also referred to as mental health conditions) brings to light a range of significant issues regarding anti-discrimination law. Within the cohort of individuals with psychosocial disabilities, fears as to unfavourable treatment upon disclosure of their disability are commonly held by virtue of the stigma that is attached to such conditions. ${ }^{34}$ The

28. M. Bell, 41 Dublin University Law Journal (2018), p. 92.

29. Nano Nagle School v Daly [2019] IESC 63, majority judgment, para. 106.

30. Case C-485/20, XXXX v HR Rail, SA de droit public, summary of request for a preliminary ruling lodged 29 September 2020 .

31. Article 2 of the CRPD defines 'reasonable accommodation' as 'necessary and appropriate modification and adjustments not imposing a disproportionate or undue burden, where needed in a particular case, to ensure to persons with disabilities the enjoyment or exercise on an equal basis with others of all human rights and fundamental freedoms'.

32. Committee on the Rights of Persons with Disabilities, General Comment No 6 - Equality and Non-discrimination (2018).

33. D. Ryan and M. Bell, 83 Modern Law Review (2020), p. 1064.

34. G. Lockwood, C. Henderson, and G. Thornicroft, 'Mental Health Disability Discrimination: Law, Policy and Practice', 14 International Journal of Discrimination and the Law (2014), p. 176 - Research conducted regarding UK case-law has indicated employee (claimant) 'reluctance in initially informing their employer that their absence from work was due to a mental health problem because of the stigma the claimants believed would be attached to such information'. 
resultant reluctance to disclose impairments to employers is significant, given that many psychosocial disabilities do not manifest physically, and the duty to provide reasonable accommodation in respect of the CRPD and Directive 2000/78 cannot feasibly be activated until such point as the duty-bearer has knowledge as to the disability. ${ }^{35}$ In other words, discrimination has not occurred where the employee has failed to disclose, which Bell and Waddington contrast with Directive 2000/78's prohibition on indirect discrimination, where the absence of prior knowledge of impairment or disability is in no way a defence for employers. ${ }^{36}$ The extent of such a disclosure is a further point of contention, Directive 2000/78 remaining silent on whether constructive or actual knowledge is required on the part of the employer for the duty to be activated, ${ }^{37}$ it being a matter for national case-law or statute. Further, where constructive knowledge is concerned, it is unclear at exactly what point a duty is placed on an employer to assess the viability of appropriate measures or accommodations in the absence of a request. It follows from a total failure to disclose a psychosocial disability that no discrimination has occurred. It would clearly be unfair on the bona fide employer to legislate to the contrary, notwithstanding that the employee's reluctance may be grounded in a rational prediction that they would be stigmatized and unfavourably treated thereafter. ${ }^{38}$ The current position is further justified by virtue of the requirement that accommodations be tailored to the needs of the particular individual. ${ }^{39}$ This notion can, however, be countered with the principle of Universal Design, and the notion that a failure to design a workplace that is conducive to the needs of all employees is in itself a form of indirect discrimination, notwithstanding that an invisible disability may be at issue in the absence of disclosure. This is examined in section 5 .

As to addressing the stigma that has been referred to, it is acknowledged that eradicating it through a hard law prohibition is likely not to be viable. Rather, awareness initiatives targeted at the employment sphere are more likely to diminish the stigma. Such initiatives ought to encourage the acceptance of individuals with such conditions. These initiatives should promote the notion that reasonable accommodation can aid a full recovery or successful management of the condition in the course of one's employment and they also ought to inform employers of the types of appropriate measures that may render an affected individual fully capable of performing the duties required of them. At present, Article 8 of the CRPD imposes on states parties a duty to raise awareness of disabilities. Notably, states parties are required to 'promote recognition of the skills, merits and abilities of persons with disabilities, and of their contributions to the workplace and the

35. A. Lawson, 'People with Psychosocial Impairments or Conditions, Reasonable Accommodation and the Convention on the Rights of Persons with Disabilities', 26 Law in Context (2008), p. 78.

36. M. Bell and L. Waddington, The Employment Equality Directive and Supporting People with Psychosocial Disabilities in the Workplace: A Legal Analysis of the Situation in the EU Member States (Publications Office of the European Union, 2016), p. 82.

37. Ibid., p. 82. They refer to the contrasting national laws regarding constructive and actual knowledge.

38. A systematic review found that disclosure of a mental illness places job applicants at a disadvantage in securing employment compared to applicants with a physical disability or no disability: E. Brohan et al., 'Systematic Review of Beliefs, Behaviours and Influencing Factors Associated with Disclosure of a Mental Health Problem in the Workplace', 12 BMC Psychiatry (2012), p. 11.

39. M. Bell and L. Waddington, The Employment Equality Directive and Supporting People with Psychosocial Disabilities in the Workplace, p.82; A. Lawson, 26 Law in Context (2008), p. 68 - Lawson refers to the particular subjectivity of accommodations regarding mental health disabilities, with the nature of effective adjustments varying case by case, subject to the personality and history of the individual. 
labour market'. ${ }^{40}$ Perhaps these provisions ought to be embraced with increased vigour going forward.

In the absence of a unified EU approach regarding the activation of the reasonable accommodation duty and an employer's knowledge as to disability or the need for reasonable accommodation, national positions will be addressed in a comparative sense. The contrasting models that are in operation across EU member states have been established by statute, implied by statute and established by case-law. There are two key models, the common metric being the extent of knowledge that is acquired on the part of the employer regarding the potential need for accommodation. Those are (1) activation through disclosure of the disability and (2) activation upon an explicit request for reasonable accommodation. Spain, the UK and Poland have their models enshrined in statute. ${ }^{41}$ The UK model is most in keeping with model (1), providing that the employer is not subject to a duty where they '[do] not know, and could not reasonably be expected to know' that the individual has a disability. ${ }^{42}$ It follows that the employer is obliged to enquire as to the need for accommodation where they have knowledge that an employee has a disability. The body of case-law that has developed on foot of this provision has encompassed cases centred on the issue of psychological impairment. ${ }^{43}$ In Gallop v. Newport City Council, ${ }^{44}$ it was established that it is ultimately the employer who must 'make the factual judgment as to whether the employee is or is not disabled'. ${ }^{4}$

In many EU member states, national experts take the view that employer knowledge may be an implied requirement for duty activation. ${ }^{46}$ In Hungary, for example, while the legislation is silent on the extent of employer knowledge required to activate the duty, the Labour Code entails a duty to act in good faith and a cooperation duty applies to both employers and employees, the national expert concluding that employees are therefore required to inform the employer of their need for reasonable accommodations as it arises. ${ }^{47}$ In the Netherlands, an Explanatory Memorandum to the relevant Act provides that the duty to provide reasonable accommodation is active 'upon request' by the individual. ${ }^{48} \mathrm{~A}$ 'best efforts obligation' applies to the employer where they become aware of

40. Convention on the Rights of Persons with Disabilities, Article 8(2)(a)(iii); note also that Article 8(2)(d) requires promotion of 'awareness-training programmes regarding persons with disabilities' and the rights of persons with disabilities.

41. M. Bell and L. Waddington, The Employment Equality Directive and Supporting People with Psychosocial Disabilities in the Workplace, p. 83.

42. Equality Act 2010 (as amended), Schedule 8, para. 20(b) - 'A is not subject to a duty to make reasonable adjustments if A does not know, and could not reasonably be expected to know- (b) in any case referred to in Part 2 of this Schedule, that an interested disabled person has a disability and is likely to be placed at the disadvantage referred to in the first, second or third requirement.' See also s.15(2) - A does not discriminate if A did not know, and could not reasonably have been expected to know, that B had a disability.

43. M. Bell and L. Waddington, The Employment Equality Directive and Supporting People with Psychosocial Disabilities in the Workplace, p. 84.

44. Gallop v Newport City Council [2013] EWCA Civ 1583; [2014] IRLR 211.

45. Gallop v Newport City Council [2013] EWCA Civ 1583, para. 41 - the employer 'cannot simply rubber stamp the adviser's opinion that [the employee] is not [disabled]' (para. 43).

46. M. Bell and L. Waddington, The Employment Equality Directive and Supporting People with Psychosocial Disabilities in the Workplace, p. 84.

47. Ibid., p. 84.

48. Netherlands, Explanatory Memorandum to the Act on equal treatment on grounds of disability or chronic illness (Memorie van Toelichting bij de Wet gelijke behandeling op grond van handicap of chronische ziekte), Tweede Kamer, 2001-2002, 28 169, no. 3, www.parlementairemonitor.nl/9353000/1/j9vvij5epmj1ey0/vi3ak82c6k2j; 
an individual's disability or chronic illness, to investigate its nature and to ascertain whether reasonable accommodation is required. ${ }^{49}$ The Netherlands model is unique given that it is a hybrid of two models: activation upon request for reasonable accommodation and/or activation upon disclosure of disability. Accordingly, in the absence of both a request for accommodation and any actual or constructive knowledge on the employer's part of the disability, no duty to investigate or assess the need for reasonable accommodation arises. ${ }^{50}$ In relation to the 'best efforts obligation', presumably a medical certificate provided for a period of absence which lists a mental health-related illness as the reason for absence would be sufficient actual knowledge of impairment/disability, the question as to whether the employer discharged their 'best efforts obligation' being a matter for evidence.

While activating the employer's reasonable accommodation duty through a disclosure as to the employee's disability or impairment seems prima facie to be a model that is fair and fit for purpose, some questions do arise. A situation may arise concerning an employee with a differential diagnosis encompassing multiple psychosocial conditions, of some of which the employer is aware. It may be argued that the duty to reasonably accommodate has been breached in respect of one of the impairments of which the employer was not aware. In such a situation, where does the employer stand? Does the duty to investigate further entail a duty to ascertain whether other impairments are at play, or has the employer discharged its duty upon having investigated whether reasonable accommodation is required in respect solely of the disclosed disabilities? This may not be fully clear. Further, as to the stigma concerns that have been referred to, a model that favours the disclosure of an individual's full diagnosis and not just their degree of impairment may be problematic. This was made clear in a recent UK EAT decision where an employee's unwillingness to properly disclose their condition led to a decision in favour of the employer. ${ }^{51}$

In some states, the duty is activated by an explicit request for reasonable accommodation as opposed to mere impairment disclosure. The Polish Act requires that individuals make their employer aware of the need for reasonable accommodation, the employee reporting their 'specific needs ... to the employer'. ${ }^{52}$ Similarly, in Spain, an employee is obliged to disclose their disability

translation of this part of the Explanatory Memorandum is provided in M. Bell and L. Waddington, The Employment Equality Directive and Supporting People with Psychosocial Disabilities in the Workplace, p. 84, citing D. Ferri and A. Lawson, Reasonable Accommodation for Disabled People in Employment - a Legal Analysis of the Situation in EU Member States, Iceland, Liechtenstein and Norway (European Commission, 2016), p. 68.

49. 'Best efforts obligation' is translated from 'inspanningsverplichting' in: D. Ferri and A. Lawson, Reasonable Accommodation for Disabled People in Employment - a Legal Analysis of the Situation in EU Member States, Iceland, Liechtenstein and Norway, p. 69.

50. Ibid., p. 68.

51. A Ltd v Z [2019] IRLR 952, para. 43. The Tribunal was wrong to fix the employer with constructive knowledge of the employee's psychiatric condition in circumstances where further investigations would not have revealed anything of any use given the employee's unwillingness to disclose. Note further: Lv Q Ltd [2019] EWCA Civ 1417. The Court of Appeal decision dealt solely with the issue of redacting the claimant's name and nature of the disability when publishing the case. The EAT decision otherwise still stands, that an employer is not fixed with knowledge of disability where the employee has only facilitated the provision of an expert opinion as to their fitness to work.

52. This translation of the provision is provided by M. Bell and L. Waddington, The Employment Equality Directive and Supporting People with Psychosocial Disabilities in the Workplace, p. 83. An accurate translation of the Act cannot be located, but the mentioned provision is Article 23(a) of Ustawa z 27 sierpnia 1997 r. o rehabilitacji zawodowej i społecznej oraz zatrudnianiu osób niepełnosprawnych. 
and to then request reasonable accommodation to that end. ${ }^{53}$ Significantly, in both instances there appears to be no obligation to investigate the need for reasonable accommodation where there is actual or constructive knowledge of the employee's disability, notwithstanding that the other model would suggest that knowledge of disability means knowledge the accommodation may be required. While this may be viewed as a constriction of the employee's rights and, further, as providing employers with a more robust defence in instances where discrimination is alleged, it may also be viewed as broadening the right to privacy for employees with disabilities, given that the medical evidence provided to the employer could be limited solely to the impairments caused by the disability. As one Canadian arbitrator has stated, 'diagnosis' and the 'nature of illness' are not synonymous terms, rather an overlap exists, 'such that a description of the nature of an illness or injury may reveal the diagnosis and in others it will not'. ${ }^{4}$ The 'nature of illness' may be compared to the impairment that is experienced for the purposes of Directive 2000/78.

It is important to pay heed to those scenarios where the impairment does not reveal the diagnosis, given that the employee's privacy is left substantially more intact, reluctance to seek the required accommodation due to stigma concerns may well be diminished, and the employer remains equipped with the required information with which to discharge their reasonable accommodation duty. In Ontario, Canada, the official policy of the Human Rights Commission requires the employer to 'limit requests for information to those reasonably related to the nature of the limitation or restriction'. ${ }^{55}$ For employers, being provided with the details of the exact impairment at the outset may streamline considerably the procedure that would ordinarily come with the duty. This would be a favourable alternative to the common and normally complicated scenario where a disability is disclosed and an enquiry duty, and the need to identify and assess potential reasonable accommodations, follows. Further, in respect of potential ways to reduce stigma, an EU-commissioned report by Bell and Waddington notes it is not always necessary for the employer to be aware of the underlying medical condition causing the limitation, rather awareness as to the functional limitations such as decreased concentration should be sufficient. ${ }^{56}$ The solution to these issues may involve a mix of the Polish, Spanish and Ontario models, whereby employees must explicitly request reasonable accommodation and adduce medical evidence as to the precise impairment(s) that are at play.

\section{Potential solutions, including universal design}

Many EU member states have neither of the two duty activation models discussed above, yet they seem compliant with the requirement to provide reasonable accommodation. These states include

53. Interpretation of the Spanish provision (RDL 1/2013, Article 68.2) is provided in L. Chacón, Country Report: NonDiscrimination, Spain 2020 (European Commission, 2020), p. 27.

54. Providence Care, Mental Health Services v. Ontario Public Service Employees Union, Local 431, 2011 CanLII 6863 (ON LA), para.33; referred to in: Ontario Human Rights Commission, Policy on ableism and discrimination based on disability: 8. Duty to accommodate (undated), www.ohrc.on.ca/en/policy-ableism-and-discrimination-based-dis ability/8-duty-accommodate, para. 8.6.1.

55. Ontario Human Rights Commission, Policy on preventing discrimination based on mental health disabilities and addictions (Ontario Human Rights Commission, 2014), p. 48. This point was originally highlighted in M. Bell and L. Waddington, The Employment Equality Directive and Supporting People with Psychosocial Disabilities in the Workplace, p. 86.

56. M. Bell and L. Waddington, The Employment Equality Directive and Supporting People with Psychosocial Disabilities in the Workplace, p. 94. 
Belgium, Germany, Luxembourg and Slovakia. ${ }^{57}$ Some member states, such as Bulgaria and Croatia, provide for disability rights through the national system, requiring employees to have their disability officially recognized by a competent public body in order for eligibility for reasonable accommodation in the workplace to arise. ${ }^{58}$ The employer is then informed of the disability by the public body, and, in the case of Italy, access to sensitive personal data is permitted only where strictly necessary. ${ }^{59}$ As was stated earlier, stronger state involvement may need to be a component of more fundamental reform of equality law concerning disability in the future. Such increased state involvement may entail the establishment of a competent state authority to add an extra dimension to the process for provision of reasonable accommodation by employers. A competent authority might, either in whole or in part, assess whether a disability exists, identify whether accommodation is required, and ascertain what appropriate measures may render the individual capable, while working with the employer to implement such measures. Competent authorities of this type have been established in Bulgaria and Croatia. ${ }^{60}$ If such models are to be adopted by other states, care would need to be taken to ensure that the option also remains for the employee to deal directly with the employer if they wish.

UK research indicates a lack of awareness on the part of middle and senior management as to what types of reasonable accommodation may be effective for those with diagnosed mental health problems, ${ }^{61}$ the invisibility of impairment being a key factor. Accordingly, increased awareness as to impairment and potential appropriate measures has been advocated. ${ }^{62} \mathrm{~A}$ competent state body could provide funding, particularly in respect of any physical adjustments required, while also serving to diminish the knowledge vacuum that exists regarding the types of accommodations that may be reasonable through equipping employers with the required knowledge.

In the UK, the state provides assistance to employees through the Access to Work (ATW) scheme. ${ }^{63}$ The employer's duty to make reasonable adjustments is laid down in the Equality Act $2010,{ }^{64}$ along with Directive 2000/78, before the UK left the EU. The ATW programme in Great Britain steps in where the required adjustments extend beyond the parameters of the employer's duty. ${ }^{65}$ The employee applies directly to the state for the relevant grant, which is paid by the Department of Work \& Pensions. Recent media publications have highlighted its effectiveness in

57. Ibid., p. 85 .

58. Ibid., p. 85.

59. Ibid., p. 86.

60. In Bulgaria, the competent authority is the Agency for People with Disabilities; in Croatia it is the Institute for Medical Assessment, Professional Rehabilitation and Employment of People with Disabilities. See M. Ilieva, Country Report: Non-Discrimination, Bulgaria 2020 (European Commission, 2020), p. 31 and I. Bojić, Country Report: NonDiscrimination, Croatia 2020 (European Commission, 2020), p. 31.

61. G. Lockwood, C. Henderson, and G. Thornicroft, 14 International Journal of Discrimination and the Law (2014), p. 179.

62. Ibid., p.179.

63. There are two schemes - one for Great Britain and one for Northern Ireland. For the British scheme, see 'Access to Work fact sheet for employers', www.gov.uk/government/publications/access-to-work-guide-for-employers/accessto-work-factsheet-for-employers . For the Northern Irish scheme, see www.nidirect.gov.uk/articles/access-work-prac tical-help-work.

64. Equality Act 2010 (Great Britain). For Northern Ireland equivalents, see www.equalityni.org/Legislation.

65. UK Government, 'Access to Work: staff guide', https://assets.publishing.service.gov.uk/government/uploads/system/ uploads/attachment_data/file/772080/access-to-work-staff-guide.pdf, para. 27. 
respect of employees that are hearing impaired, through the allocation of up to $£ 57,000$ per person in state money for use in the hiring of interpreters, note-takers, etc. and the success of this in rendering otherwise impaired individuals capable of reaching their full potential in the course of their employment. ${ }^{66}$ The idea of having a strong state scheme which assists in the employment of employees with disabilities is effective and likely to remove uncertainty for employers and employees where the measures required may be beyond a firm's resources. Importantly, in respect of macro-economic efficiency, the model has been found to be highly effective. A report commissioned by the UK government refers to the $£ 7$ billion cost to the UK exchequer of funding out-of-work benefits for individuals with a disability, compared to a mere $£ 330$ million on specialist disability employment support. ${ }^{67}$ It was also found that for every pound spent on ATW, $£ 1.48$ is recouped by the exchequer, the social return on the investment being even more considerable. ${ }^{68}$ As previously stated, Recital 21 of the Framework Directive states that, in assessing whether a disproportionate burden is imposed, account should be taken of the 'costs entailed', the 'scale and financial resources of the organisation or undertaking' and the 'possibility of obtaining public funding or any other assistance'. ${ }^{69}$ If an employee in the UK avails of the ATW scheme, this can result in a 'win-win' situation for both the employer and the employee. The employee is facilitated in accessing employment and the employer can employ the employee without incurring the additional expenditure which might have been required to make adjustments for the employee's disability. It is unclear whether the UK model has had an impact on employment rates for people with disabilities, but there is evidence that such rates are better in the UK than in other states. ${ }^{70}$ In Ireland, there are also state grants available for employers (not employees) but there is a lack of data on the effectiveness of the grant schemes. ${ }^{71}$ Outside the EU,

66. Mind The Gap Films, 'London's Calling' (Ireland: RTÉ One, 23 May 2019), documentary broadcast on Ireland's state television network, Raidió Teilifís Éireann, highlighting the UK's Access To Work programme and its positive impact on employees that are hearing-impaired. Such employees may obtain interpreters, note-takers, etc., funding for which is provided by the state, with a maximum annual spend per person with a disability of $£ 57,200$. The documentary focused on the deficiencies of the Irish system in not providing such accommodations to individuals, focusing on deaf Irish workers who, having moved to the UK, are reaching their full potential in employment, something they believe was not possible in Ireland. See also Evening Echo, 'Support Deaf People in Accessing Work', 22 April 2019, www. echolive.ie/corkviews/arid-40147190.html.

67. L. Sayce, Getting in, staying in and getting on: Disability employment support fit for the future, Cm 8081 (Department for Work and Pensions, 2011), p. 7.

68. Ibid., p.7, p. 15 and p. 124.

69. Directive 2000/78, recital 21.

70. In 2018, in the UK, there was an employment rate of $74 \%$ for those with moderate disability and $33.9 \%$ for those with severe disability. These rates were better than the European average, cited earlier in this paper. European Disability Expertise, Master Tables Concerning EU 2020: year 2018, Table 2.

71. The Department of Social Protection provides a range of supports for employers to assist them in their provision of reasonable accommodation. These supports include training, the development of policies and procedures, assistance with accommodating new employees with disabilities, along with the retention of those who acquire an injury. Support is provided primarily through the provision of grants, the level of uptake of which is unknown. Data to that end might enrich any discussion as to their effectiveness. See more at Employer Disability Information (EDI), 'Employer Disability Grants', www.employerdisabilityinfo.ie/supports-and-funding/employer-disability-grants; Citizens Information Board, 'Employment and Disability', www.citizensinformation.ie/en/employment/employment_and_disability/. Again, the supports are mainly grants that appear to be capped. This state involvement is favourable, but an increased spend on the part of the state and the establishment of a competent authority to fully manage the provision of reasonable accommodation would be more favourable. 
there are other examples of best practice which could be drawn upon, such as the Job Accommodation Network (JAN) in the USA. ${ }^{72}$

This possibility of increased state involvement in the provision of reasonable accommodation to employees has strong potential. For employees, it is conducive to reducing stigma concerns and increasing employee requests for accommodation where it is required. It may also bring about the provision of more robust reasonable accommodation, capable of rendering a greater number of individuals capable of undertaking employment. For employers, increased state involvement in the process of reasonably accommodating employees with disabilities would potentially simplify what is often an onerous and ambiguous process of making enquiries, carrying out assessments and eventually implementing effective appropriate measures. While it may require an increased upfront spend on the part of the exchequer, this is likely to be justified when net benefits of both a cost and social nature are factored in.

A model whereby the provision for those individuals with disabilities is carried out in a proactive as opposed to a reactive manner could potentially reduce or eliminate the need for the reasonable accommodation system. As defined in Article 2 of the CRPD, 'universal design' is the design of "products, environments, programmes and services to be usable by all people, to the greatest extent possible, without the need for adaptation or specialized design'. ${ }^{73}$ Further, it 'shall not exclude assistive devices for particular groups of persons with disabilities where this is needed'. ${ }^{74}$ Article 4 establishes a duty to undertake or promote research and development of universally designed goods, services, equipment and facilities' ${ }^{75}$ It further requires the promotion of 'universal design in the development of standards and guidelines'. Article 9 on Accessibility requires states to ensure equal access to the physical environment and other facilities and services. ${ }^{76}$ Article $27(1)$ refers to the need for a 'work environment that is open, inclusive and accessible to persons with disabilities'. The requirements regarding inclusiveness and accessibility may be considered to be in a similar vein with the concept of Universal Design. $^{77}$

The move towards Universal Design is part of a general movement in disability law away from 'special needs' approaches towards more universalist or mainstreamed approaches. ${ }^{78}$ While the principle of Universal Design (and Inclusive Design) has been discussed to some extent in regard

72. See https://askjan.org; B. Loy, Workplace Accommodations: Low Cost, High Impact (Job Accommodation Network, 2017). JAN is funded by a contract from the U.S. Department of Labor.

73. Convention on the Rights of Persons with Disabilities, Article 2.

74. Ibid., Article 2.

75. Convention on the Rights of Persons with Disabilities, Article 4(1)(f) - Article 4 entails the general obligations applicable to all parties which have ratified the convention.

76. See also Committee on the Rights of Persons with Disabilities, General Comment No 2 - Article 9: Accessibility (2014).

77. Directive (EU) 2019/882 of the European Parliament and of the Council of 17 April 2019 on the accessibility requirements for products and services, [2019] OJ L 151/70, states in recital 50 that accessibility should be achieved by the systematic removal and prevention of barriers, preferably through a universal design or 'design for all' approach, which contributes to ensuring access for persons with disabilities on an equal basis with others. Recital 50 also states: 'Accessibility and universal design should be interpreted in line with General Comment No 2 (2014) of the Committee on the Rights of Persons with Disabilities on Article 9: Accessibility.'

78. A. Lawson, 'Disability Law as an Academic Discipline: Towards Cohesion and Mainstreaming?', 47 Journal of Law and Society (2020), p. 581. 
to accessibility of buildings, ${ }^{79}$ accessibility of products and services ${ }^{80}$ and inclusive education, ${ }^{81}$ it is under-discussed in the field of employment equality law.

Were this principle of Universal Design to be fully implemented, the need for reasonable accommodation would substantially diminish, given that work environments would be developed from the outset to be conducive to the needs of those with both physical and psychosocial disabilities. This would reduce the above-mentioned concerns in respect of disclosure, enquiry duties and duty activation. Gradual implementation of this model, as the CRPD suggests, ${ }^{82}$ would appear to be the only realistic course of action. And Universal Design would complement the existing reasonable accommodation system, rather than replacing it completely.

If a categorical requirement was inserted into future equality legislation that the model of Universal Design be adopted, there would be a number of issues to be resolved.

In respect of physical adjustments, the prospect of adapting many existing workplaces to be fully wheelchair accessible for example, poses various challenges. Indeed, the current EU framework does, however, seek to make public spaces, workplaces, etc. accessible to all through the European Disability Strategy 2010-20, ${ }^{83}$ informed by the CRPD. ${ }^{84}$ As to the implementation of physically accessible workplaces across the board, including those that are not open to the public, cost concerns would arise. While the adaptation of this model for newly constructed premises may be viable and not too burdensome, an immediate implementation of the model in respect of existing premises is perhaps not so feasible.

Another area of Universal Design may include flexible working hours to facilitate those individuals with psychosocial disabilities. In respect of individuals with Autism Spectrum Disorder (ASD), a universally designed workplace may be designed with their sensory needs in mind, or interviews of prospective employees would ordinarily not entail open-ended questions so as any impairment in respect of abstract thinking does not put the individual at an unfair disadvantage. ${ }^{85}$

79. R. Imrie, 'Universalism, Universal Design and Equitable Access to the Built Environment', 34 Disability and Rehabilitation (2012), p. 873; A. Heylighen, V. Van der Linden and I. Van Steenwinkel, 'Ten Questions Concerning Inclusive Design of the Built Environment', 114 Building and Environment (2017), p. 507.

80. D. Ferri, "The European Accessibility Act and the Shadow of the "Social Market Economy", 45 European Law Review (2020), p. 660.

81. M. Capp, 'The Effectiveness of Universal Design for Learning: A Meta-Analysis of Literature Between 2013 and 2016', 21 International Journal of Inclusive Education (2017), p. 791; K. Rao, M. Ok and B. Bryant, 'A Review of Research on Universal Design Educational Models', 35 Remedial and Special Education (2014), p. 153.

82. The above-mentioned reference to universal design in the Convention on the Rights of Persons with Disabilities by way of articles 2 and 4 is primarily centred around the promotion of research and development in respect of the model. There is no categorical requirement being imposed at this juncture, but it is presumed that the intention is to work towards this.

83. European Disability Strategy 2010-2020: A Renewed Commitment to a Barrier-Free Europe, COM (2010) 636 final The Commission acknowledges that the EU 'has a long way to go' in achieving full accessibility. Further, the Commission 'proposes to use legislative and other instruments, such as standardisation, to optimise the accessibility of [inter alia] the built environment...'.

84. As to universal design in respect of physical accessibility, the EU framework is important. It is guided by the Convention on the Rights of Persons with Disabilities, Article 9 of which on Accessibility provides that States Parties shall take appropriate measures to ensure persons with disabilities can access, on an equal basis to others, inter alia, workplaces. They must also ensure that private entities open to the public offer facilities and services that take into account all aspects of accessibility for persons with a disability.

85. National Disability Authority, Reasonable Accommodations for people with Autism Spectrum Disorder (National Disability Authority, 2014), p. 13 - 'People with ASD may have difficulties thinking about the reasoning behind the question thus they are not able to establish the information the interviewer is seeking'. 
To provide for all areas of disability is arguably something that will take years of research and gradual implementation. The absence of a requirement for medical evidence prior to availing of such reasonable accommodation may lead certain employees, who do not have a disability, to unscrupulously avail of the measure in the absence of real need. This would create concerns for employers, particularly smaller employers for whom profit margins may be affected as a result of their implementation of the model.

Universal Design would not remove the need for the current reasonable accommodation model. The person-specific nature of many required adjustments is such that a reactive element would have to remain. The removal of the reasonable accommodation duty could in fact diminish employee rights given that those who require more complex or novel adjustments may not be sufficiently accommodated by the supposed universally designed workplace. Possibly the solution may be found in a hybrid of the two models, whereby the physical and organizational elements of the workplace are designed with the principle of Universal Design in mind, thus reducing the degree of disclosure, etc. while person-specific reasonable accommodation may still be sought for those individuals whose needs are not satisfied by the universally designed workplace. These considerations have also been highlighted by Lawson, who states that universalist approaches to law and policy do not require silence on disability or impairment. She points out that, in order to effectively ensure that a particular law or policy is not ableist, levels of functional ability falling short of conventional ability norms will often require explicit acknowledgement and provision. ${ }^{86}$

\section{Conclusion}

The inclusion of all individuals with disabilities in employment is an important goal. However, this has not yet been accomplished and it is apparent that achieving this goal has been, and will continue to be, a complicated process. The EU legal framework on employment disability law as prescribed by Directive 2000/78 and as informed by the CRPD seeks to give effect to the principle of equal treatment via the provision of reasonable accommodation. In many states, the responsibility to provide reasonable accommodation is mainly imposed on employers. The 'Competence Defence' in the Framework Directive could have been more strongly drafted, to prescribe more precisely the circumstances in which an individual may be found not to be competent to perform the post's essential functions.

Stigma concerns regarding psychosocial disabilities likely reduce employees' willingness to seek the required accommodations and also raise questions as to the activation of an employer's duty. Duty activation upon disclosure of a disability seems prima facie most conducive to the principle of equal treatment since minimal effort is required of the individual. ${ }^{87}$ However, questions as to the extent of an employer's subsequent enquiry duty and the notion that rationally-held employee stigma concerns may reduce disclosure, are significant. The alternative model whereby activation occurs upon request for accommodation is more considerate of the individual, since accommodation can be requested without the need for full disclosure of diagnosis, the employee only needing to reveal the nature/degree of impairment. Were such a model implemented, member states could establish national competent authorities to liaise between the individual and employer

86. A. Lawson, 47 Journal of Law and Society (2020), p. 583.

87. The duty is likely activated where an employer has constructive knowledge that the individual has a disability. This may include, for example, a scenario where a medical certificate submitted by the employee indicates the individual was absent as a result of stress or any other mental health-related condition. 
in order to assess whether a disability is present and then ascertain and implement any required adjustments.

The Universal Design model shows strong potential, but its implementation will be gradual and to deploy it as an outright alternative to the current reasonable accommodation model would diminish employment disability rights, since no facility would exist for individuals to request novel or less common appropriate measures, not accommodated by the supposed universallydesigned workplace. The establishment of competent authorities in Member States has the potential to alleviate many of the concerns raised in this article in respect of the almost entire reliance on employers to discharge the duty to provide reasonable accommodation for employees with disabilities. Member States are free to take measures which go beyond the minimum standards in the Directive, and do not need to wait for amendments of the law at EU level to take action. Participation in employment by individuals with disabilities is imperative. While much has been accomplished to that end, there remains a long way to go.

\section{ORCID ID}

Darius Whelan (D) https://orcid.org/0000-0003-4408-8529 